\title{
How free is sow stall free? Incremental regulatory reform and industry co- optation of activism
}

\author{
Rachel Carey, Christine Parker and Gyorgy Scrinis
}

Law \& Policy, 2020, 42(3), 284-309

\begin{abstract}
This article critically examines how interactions between social movement activism, supermarkets, and the pork industry led to the voluntary adoption of "sow stall free" standards in Australia. We "backwards map" the regulatory space behind "sow stall free" products to show how the movement against factory farming became selectively focused on the abolition of one form of confinement for sows, rather than other forms of confinement and the conditions of the sows' offspring, the piglets that are consumed. We argue that this facilitated an incremental shift to "sow stall free" production, allowing the concept of pig welfare to be corporatized in a way that maintains the dominant model of factory farmed pig meat production.
\end{abstract}

\section{Introduction}

The introduction of bans on sow stalls (also known as gestation stalls or crates) for pregnant pigs in Europe, the United Kingdom, Canada, New Zealand and some states of the US ${ }^{1}$ suggests that market activity driven primarily by economic growth can be checked by the activism of social movements. Australia has not yet legislated to ban sow stalls. However, around $80 \%$ of the Australian sow herd is now in "sow stall free" production systems and "sow stall free" marketed and labelled products are widely available in supermarkets 
(Australian Pork Limited 2017). In late 2016, the industry body, Australian Pork Ltd (APL), ${ }^{2}$ went so far as to call for a government legislated ban on the use of sow stalls by the nation's pig producers (Locke 2016), a reversal of its earlier opposition to such a ban (APL, 2011).

This article examines how interactions between social movement activism, supermarkets, and the pork industry led to the voluntary adoption of "sow stall free" production standards across most of the Australian pork industry. We show how the social movement campaign against "factory farming" of pigs selectively focused on the issue of freeing sows (breeder pigs) from confinement for strategic reasons. This enabled supermarkets and the pork industry to buy into pig welfare by exploiting the representation of "sow stall free" as an animal welfare innovation. This "sow stall free" version of pig welfare in turn allows the existing model of intensive pig meat production to continue without significant disruption. In this sense, we argue, it represents a form of industry co-optation of animal activism.

The first part of this paper describes our theoretical framework. We introduce the concepts of “regulatory capitalism" (Levi-Faur 2017), "regulatory space” (Hancher and Moran 1988) and industry "co-optation" (King and Busa 2017; Jaffee and Howard 2010) to explain how industry, government and social movement activists interact with each other as they each seek to use regulation to create and contest market boundaries for their own purposes. In this paper, the focus is on market-based governance responses to social movement activism that aims to limit animal exploitation by campaigning against "factory farming" (Harrison 1964). As the first part also explains, we use a "backwards mapping" research approach (developed by Parker and co-authors: see Parker 2014; Parker, Johnson and Curll 2019) to examine the regulatory space behind the claims on food labels. ${ }^{3}$ 
The second part briefly describes international developments in the governance of sow stalls, which have included both government regulation and market-led voluntary accreditation and labelling schemes. We then set out how Australia currently regulates sow stalls and describe our methods for "backwards mapping" the regulatory space behind the emergence of "sow stall free" production in the Australian marketplace. This methodology starts with what the consumer sees in the market (e.g. marketing claims concerning animal welfare on pork and ham products) and traces back the networks of public and private governance throughout the supply chain that create and support the claims on the label. Finally, it critically evaluates the underlying production practices against the claims made and governance processes used.

The third part reports our findings. We show how the issue of sow stalls came on to the public and policy agenda in Australia as a result of normative pressure from animal welfare activists, technological change and regulatory developments in the UK and EU. Government reluctance to ban sow stalls created the conditions for a market-based response. Coles (one of Australia's two major supermarkets) and industry body APL each defined their own standard for "sow stall free" production and labelling. These "sow stall free" standards became a key device for industry to buy into and co-opt animal welfare activism about factory farming.

The fourth part of the paper concludes that "sow stall free" does represent a small shift in the very boundaries of the market. Unlike other well-known voluntary certification and labelling standards, such as "fair trade", "organic" and "free range" (Jaffee and Howard 2010; Parker, Carey, and Scrinis 2019), "sow stall free" is not merely a market niche aimed only at conscientious consumers. The vast majority of pig products sold in Australia are now produced to a "sow stall free" standard. The APL version of that standard will likely be enshrined in new mandatory regulatory standards for pig welfare (Animal Health Australia 2017), formalising a change in the degree to which sows can be exploited as "animal 
machines" (Harrison 1964). We argue that "sow stall free" labelling and marketing exploits this small incremental victory for the animal movement in a way that subtly suggests a larger, more transformative change has taken place. In this way, "sow stall free" corporatizes animal welfare through the co-optation of activism against factory farming of animals.

\section{Conceptual framework: Regulatory Capitalism, Regulatory Space and Industry Co-optation}

\subsection{Regulatory capitalism and regulatory space}

David Levi-Faur (2017, 289-290) has argued that capitalism is constantly "being constituted, shaped, constrained and expanded" by "a patchwork of regulatory institutions, strategies and functions". Regulation creates markets through the enforcement of concepts such as private property, companies, stock markets, competition law and insurance. At the same time, social and financial risk in capitalist societies constantly creates new demands for regulation to constrain commodification of labour, land and nature. Political, economic and social actors "invest" in regulation to help create and stabilise markets through commodification, and to constrain and de-commodify markets in the name of social, political and environmental goals (see also Polanyi 2001). Thus, environmental regulation seeks to de-commodify certain uses of natural resources (e.g., to preserve watersheds or endangered species) and fair work regulation puts limits on the commodification of human labor (e.g., through the eight-hour working day).

Regulatory studies scholarship highlights that there is no clear division in practice between public and private spheres of activity in "regulatory space" (Hancher and Moran 1998). Rather than acting as "takers" of regulation made exclusively by public institutions, businesses themselves often acquire the status of "governing institutions", and regulation is 
constantly shaped by complex interactions between state, civil society and market-based actors (e.g., Braithwaite and Drahos 2000; Schneiberg and Bartley 2008; see also Streeck 2011).

In particular, industry actors often resist regulation to limit market activities, using devices such as regulatory impact analysis or international trade rules to re-frame proposed regulation as a stultifying anti-economic growth force. Edelman (2017) shows, in the context of civil rights laws in the US, that even when new regulation is mandated, corporate actors are adept at co-opting the implementation of laws through their own compliance activities. In another form of industry co-optation, industry may respond to social movement activism by proposing its own voluntary regulatory responses that create new market opportunities. For example, private corporate social responsibility standards may become marketing niches (Streeck 2011) and forestall or influence official government regulation (King and Busa 2017). Yet, as we argue here, industry responses to regulatory pressure can also represent small but meaningful incremental improvements, particularly where social movements maintain pressure on businesses. In this paper, we argue that this type of reductionist incremental reform represents a third form of industry co-optation of regulatory pressure.

\subsection{Social movement activism in regulatory capitalism}

Social movements that put normative pressure on corporations and state authorities are considered in much scholarship to be drivers of legitimate regulatory innovation. In their seminal work on responsive regulation, Ayres and Braithwaite (1992) argue that public interest groups are crucial to holding state regulators and regulated industries accountable. Parker (2002) has also shown that vulnerability to social movement activism is vital for effective corporate self-regulation and compliance. Much recent scholarship on transnational business governance concerns the capacity of labelling and certification standards developed 
in response to NGO campaigns to improve labor and environmental conditions (e.g., Bartley et al 2015). Of particular relevance to this paper, food movement activists and animal advocates focused on abolishing factory farming of animals have been especially prominent in recent years (Fraser 2008; Miele and Lever 2013; Miele 2011; Parker et al. 2017).

The processes by which social movements influence regulatory and market change are underexamined in regulatory studies literature in comparison to the focus on regulatory agencies and industry self-regulation schemes (cf King and Pearce 2010). Moreover, contests over the commodification of animals have rarely been a focus of regulatory studies scholarship, despite the fact that highly contested intensive animal operations are an important feature of all developed capitalist economies. The most intensively produced meats, chicken meat and pig meat, are now the most commonly consumed globally, and Australia is one of the three highest consumers (per capita) in the world (OECD 2018).

King and Pearce's (2010) analysis of social movements and institutional change shows that social movement politics are a source of dynamism, not just drag, in markets. Social movement contestation can generate momentum to change markets by mobilising material and cultural resources, appealing to third parties (e.g., consumers or investors) for moral and material support and by constructing new market categories and standards of accountability. Indeed, King and Pearce $(2010,261)$ conclude that it is "the initial conflict between the powerless and the powerful" that initiates change in the market, and they suggest that, "institutional changes in the market do not normally occur without a push from actors at the margin".

Elzen et al (2011) provide a detailed analysis of how normative pressures lead to change, focusing on case studies of the pig industry in the Netherlands. They identify the role of 
resource mobilisation (e.g., of networks and public pressure), the framing of issues (including the impacts of external shocks) and political opportunity structures. We draw on this understanding of the dynamics of normative pressure to identify some key factors that led to the introduction of private "sow stall free" standards in the Australian marketplace (see also Fligstein and Macadam 2012). As we also show, this does not mean that social movement campaign goals, such as the campaign to abolish factory farming of animals, are adopted in whole by market actors. Rather social movement activism is generally co-opted or "corporatized" for industry and market consumption.

\subsection{Industry Co-optation of Social Movement Activism}

King and Busa $(2017,549-550)$ conceptualise corporatization as a "process by which corporate interests come to engage with ideas initiated by a social movement and, ultimately, to significantly shape discourses and practices initiated by the movement... in pursuit of profit and/or in hopes of forestalling government regulation”. King and Busa show how corporate actors have taken over strategic action fields (Fligstein and McAdam 2012) initiated by social movements in relation to breast cancer activism, organic food and recycling. They also demonstrate how corporate actors simplify and scale up social movement ideas to ensure compatibility with industrial systems of production, leading to the emergence of mass markets for the co-opted version of the social movement's ideas.

Social movements also selectively frame issues in ways that enable the general public and corporations to engage with them (Georgallis 2017; Holzer 2006), and hence facilitate corporatization. The Australian animal advocacy movement focused specifically on the poor welfare of sows in stalls in campaigns against factory farming of pigs (e.g., Voiceless 2013). We argue below that this influenced the emergence of "sow stall free" in the Australian marketplace. This highlights the incrementalism inherent to political consumerism and 
voluntary market-based governance reform. Activist movements selectively focus on a single practice (the use of sow stalls) within a production system (factory farming of pigs) that consists of a host of other objectionable components. They do so in order to obtain public attention and industry buy-in . Yet this selective focus on one component in a multiplex system enables industry co-optation of social movement concerns via small incremental reforms that can then be represented as if they were transformative.

This is an example of the way in which the food industry responds selectively to social movement pressures, choosing to appropriate "those demands that best fit with expanding market opportunities and profits" (Friedmann 2005: 231). Incremental improvements in animal welfare are thus consistent with Harriet Friedmann's (2005) identification of a "corporate-environmental food regime" in which large retailers and agro-food corporations selectively appropriate the demands of environmental, food safety, animal welfare, fair trade and other social movements in order to maintain power in the implicit and explicit negotiation and construction of new rules set out in public regulation and increasingly in private certification and quality assurance schemes (Friedmann 2005).

However, as King and Busa (2017) show, corporatized simplification and scaling up also produce social activist "response movements", which can create ongoing dynamism and change in the regulatory space. This opens up the possibilities for further activism for reform, which is also likely be co-opted and corporatized. As Friedmann (2005: 258-9) notes, the corporate-environmental food regime is heavily contested by social movements challenging the privatization inherent to market-based regulation. 


\subsection{Research approach: Backwards mapping the regulatory space behind retail markets}

We have suggested above that wherever there is conflict and contention over values or policy goals in relation to markets, there is conflict and contention over regulation. The significance of market, government and civil society interactions over the regulation of markets goes beyond individual regulatory outputs (such as legislation, court cases or voluntary standards) to the very shape of the market - what products are available, how they are produced and sold, what is and is not commodified, and even the very scale of production and consumption.

Traditional legal and policy research methods, focused on formal state institutions, are of limited relevance in evaluating the extent to which social movement pressure brings about higher standards through market-led governance. If we want to understand how markets can be constrained and regulated - or conversely how attempts at regulating markets are co-opted and transformed - then a regulatory capitalism approach implies that we should start by looking at the shape of the market, before working backwards to understand the interactions in the regulatory space that shape the market.

Parker (2014) has previously suggested "backwards mapping" markets in order to understand how networks and coalitions of actors create shifting alliances of power that change the way markets are regulated. The term "backwards mapping" is inspired by Dorothy Smith's grounded "institutional ethnography" (Smith 2005) and the sociology of the everyday place of law developed by Ewick and Silbey (1998). That is, we take products that are visible in everyday supermarket aisles and use our research to "enlarge the scope of what becomes visible from that site, mapping the relations that connect one local site to others" (Smith 2005:29, emphasis added). This "sociology for people" (Smith 2005) seeks to unpack the complex social and institutional arrangements within which everyday experience is 
embedded. Like Ewick and Silbey (1998), we focus on the way that regulation is implicated in this everyday world, rather than starting with regulatory standards. We also draw on the insights of regulatory studies scholarship, which understands regulation as emerging from interactions and power contests between government, industry, civil society organizations and individuals (Eberlein et al 2014; King and Pearce 2010). The information, stories and images on food labels (and what they leave out) reflect the outcomes of those contests.

The first step in backwards mapping is the retail space itself, the place where individual consumers encounter the market. We begin with a visual sociology of the products available for consumer choice in their retail context, paying careful attention to the claims made about animal welfare (pictures, signs, symbols, context) and visual appeals to regulatory support (for example, credence claim accreditation logos) (similar to Richards, Lawrence, and Burch 2011: 38-39).

The second step is to investigate each appeal to values and regulation on the label using critical supply-chain analysis (Dixon 2002; Guthman 2004) and regulatory network analysis (Eberlein et al 2014). We trace back the food supply chain and the plurality of governance arrangements created by networks of public and private actors to support label claims and the production practices that underpin the claims. We compare the animal welfare claims on products with information about the accreditation schemes and production practices behind them through desktop review of the websites of accreditation organizations and producers, and through interviews with representatives of the accreditation organizations, retailers, producers and animal welfare and consumer NGOs.

The third step is to critically evaluate, as far as possible, the production practices in terms of the values and interests that are represented and those that are sidelined. In this case study, 
analysis based on desktop research was supplemented by a multi-stakeholder workshop to explore the issues and a comprehensive analysis of newspaper articles and policy documents related to pig welfare regulation, civil society campaigns, and market initiatives over the last 25 years. The results of this latter data collection have been reported in more depth elsewhere (Parker et al 2017, 2019).

We have previously applied this approach to contests over cage versus free range egg production (Parker et al. 2017; Carey, Parker, and Scrinis 2017) and higher welfare chicken meat production (Parker et al 2018). In doing so, we make visible the ways in which regulation and markets are intertwined. The following part explains the background and justification for our focus on the contestation of sow stalls, and the data collection methods used.

\section{Background and Methods}

\subsection{Animal welfare and intensive pig farming}

Citizen concern about the welfare of intensively farmed animals (egg laying hens, meat chickens and pigs) has grown since the introduction of "factory farmed" production systems in the 1960s (D'Silva 2000; Harrison 1964). The freedoms of these animals have been progressively restricted as market pressures encouraged a focus on productivity gains at the expense of animal welfare (McInerney, 2004). However, in 1997, animals were legally recognized as sentient beings for the first time in Europe after Compassion in World Farming (2009) $)^{4}$ submitted a petition to the European Parliament following much campaigning by influential NGOs (Miele and Lever 2014). In the same year, the Scientific Veterinary Committee of the European Union $(1997,146)$ conducted a review of the welfare of pigs in 
intensive systems, concluding that, "some serious welfare problems for sows persist even in the best stall-housing system".

Pigs experience some of the most intensive production systems of all farmed animals. Around $90 \%$ of farmed pigs in the United States, Europe and Australia are in intensive systems of indoor pig production (Park, Min, and Oh 2017; APL 2018). In intensive systems, the piglets that are consumed are raised in group pens on concrete or slatted floors, sometimes with the addition of straw or other litter, while the sows (mother or "breeder" pigs) spend most of their lives confined individually in various types of "stalls" or "crates" used at different stages of the breeding cycle (Pederson 2017). Yet pigs are known to be intelligent, social and playful animals (Scientific Veterinary Committee of the European Union 1997). Concerns have grown about the impact of this confinement on pig welfare, and particularly, on the ability of pigs to express natural behaviors, such as "rooting" for food and nesting (e.g., Voiceless 2015). Pressure from animal welfare groups and consumers has increased worldwide against factory farming and for better pig welfare, with a particular focus on removing sows from a system of confinement known as "sow stalls" (also known as gestation stalls or crates) (Voiceless 2012; Compassion in World Farming 2018).

Sow stalls are narrow cages that are just big enough to accommodate a sow, but not big enough to allow the sow to turn around. They were introduced in the 1960s to increase the efficiency of pig meat production, enabling pigs to be housed in a way that maximizes productivity and use of space, and minimizes animal management (Caulfield and Cambridge 2008; van Barneveld 2013). Sow stalls also enable individual rationing of feed and prevent aggression between sows (Scientific Veterinary Committee of the European Union 1997). However, sows in stalls exhibit a range of stereotypical behaviors, such as bar biting and 
rubbing on pen surfaces, which are generally regarded as indicators of poor welfare (Rhodes et al. 2005).

\subsection{Government action on sow stalls around the world}

The conclusions of the Scientific Veterinary Committee of the European Union (1997) about the welfare issues associated with sow stalls triggered action in Europe to ban them. ${ }^{5}$ Sow stalls were banned in the UK from 1999 (Pickett, Crossley, and Sutton 2014). In 2001, the EU announced that a region-wide ban would begin in January 2013 (European Commission 2008). ${ }^{6}$ Sow stalls have also been banned in Canada (Canadian Pork Council and National Farm Animal Care Council 2014), New Zealand (National Animal Welfare Advisory Committee 2010) and in some states of the United States (Shields, Shapiro and Rowan 2017). ${ }^{7}$ In the US, many food companies have pledged to go "gestation stall free" (Humane Society International 2017). Food service companies such as McDonalds, Burger King and Subway have made commitments to remove sow stalls from their US supply chains (Humane Society International 2017). In 2018, Smithfield Foods (2018), the world's largest pig meat producer, announced that its US company-owned sow farms were free of sow stalls. Cargill (2018) and ConAgra (2012), huge US-based multinational food companies, have also made commitments to move to sow stall free production.

However, there are differences in the completeness of the "bans". The UK does not allow the use of sow stalls at any point during the sow's gestation (Pickett et al. 2014). Legislation in the EU and Canada allows the use of stalls for the first four weeks of a sow's pregnancy in “partial bans" (European Commission 2008; National Farm Animal Care Council 2014). ${ }^{8}$ As we shall see, Australian "sow stall free" still allows some time in a sow stall but considerably less than in the EU (see Table 2 below). ${ }^{9}$ Moreover most systems still allow confinement in farrowing crates (from before birth until weaning) and do not require outdoor access nor 
enrichment and bedding in indoor housing (discussed further below). Thus, sow stall bans do not represent a fundamental change to the nature of industrial pig farming.

\section{3 "Sow stall free" in Australia}

In Australia The Model Code of Practice for the Welfare of Animals - Pigs sets the standards for the welfare of farmed pigs, and has been legislated in most Australian states (Victorian Government 2012; New South Wales Government 2009; South Australian Government 2012; Western Australian Government 2010; Tasmanian Government 2013; Queensland Government 2012). ${ }^{10}$ The Model Code was last revised in 2008 (see Figure 1), when a review of the evidence concluded, in contrast to the earlier European review, that "there is insufficient scientific justification to ban the usage of stalls completely" (Caulfield 2007, 22). The Australian review was not carried out by an independent panel of experts, as the EU review had been, but by consultants contracted to review the potential impact of the regulation on the pig industry (Caulfield 2007). Instead of banning sow stalls, the revised model code reduced the use of sow stalls from sixteen weeks to six weeks, with a ten-year phase in period until 2017 (Primary Industries Standing Committee 2008; Lee 2007).

Yet by 2017, a voluntary ban on sow stalls stricter than that legislated in the EU had been taken up by over $80 \%$ of the pig industry in Australia, with the industry body APL going further and calling for a new regulatory standard (APL 2017). This paper examines how this occurred.

\subsection{Data collection and analysis}

Using the "backwards mapping" approach (described above) the first part of our research involved a survey of fresh and processed pig meat products on display at the four major supermarket chains in Australia (Coles, Woolworths, IGA and Aldi), independent retailers 
and farmers' markets. ${ }^{11}$ This showed that "sow stall free" is now the dominant higher welfare claim made on pig meat products. Two other higher welfare claim accreditations also appeared on products - “outdoor bred, raised indoors on straw”, which represents around 5\% of the market (Australian Pork Ltd 2018b) and "free range", which also represents around 5\% of the market (Australian Pork Ltd 2018a).

We conducted a comprehensive desktop review of the websites of producers, retailers and the organizations that create and administer accreditation schemes in order to uncover the production and supply chain practices behind the products' marketing claims. This assisted in mapping the interplay of social movement activism, technological innovation and regulatory developments that led to the adoption of "sow stall free". We also examined publicly available documents relating to contestation between key stakeholders in the regulatory space over the meaning of "sow stall free" and other higher pig welfare labels. These documents included media releases, annual reports, policy statements and submissions to policy development processes. In addition, we reviewed all newspaper articles in major Australian newspapers for the last 20 years concerning these issues.

We carried out a total of 18 interviews with representatives of the major retailers and accreditation organizations, producers, animal welfare groups and consumer NGOs. A workshop was also held with representatives of these organizations to explore the issues further. Informed consent was gained for the interviews and workshops, which were held during 2015 and 2016. The workshop lasted 2.5 hours and interviews lasted 45 to 60 minutes. Both were audio-recorded with the permission of participants. The results of the interviews, workshop and desktop review were coded thematically (Guest, McQueen, and Namey 2012) to identify interactions between key actors in the governance networks behind the labels, and to compare the label claims to the production practices. Material from the interviews and 
workshops has informed our analysis, but we have not presented direct quotes here to protect the confidentiality of respondents, as there is a relatively high risk that participants may be identifiable.

\section{Findings}

Our analysis shows how social movement activism was able to focus public and market attention on the issue of sow stalls, and how supermarkets (and ultimately industry) responded with a voluntary sow stall ban. We then critically examine the ways in which the creation of Australian "sow stall free" represents a reductionist and over-simplified response to the issues represented by factory farming of pigs, consistent with King and Busa's (2017) definition of industry co-optation of social movement activism. Finally, we consider the potential for social activist "response movements" (King and Busa 2017) to lead to further change.

\subsection{Social movement activism against factory farming and sow stalls}

After the Australian government's decision in 2008 not to introduce a ban on sow stalls (Primary Industries Standing Committee 2008), animal welfare groups and Members of Parliament from the Australian Greens party ${ }^{12}$ continued to mobilize public pressure to improve the welfare of pigs in intensive production systems. Animal welfare groups, such as Animals Australia (2012) and Voiceless (2005), had campaigned since the early 2000s to abolish all factory farming of egg laying hens, meat chickens and pigs in Australia. Australian animal activists expressed a broad range of concerns about the conditions of pigs in factory farming systems, such as the various procedures used to manage pig health and behavior (e.g., castration, teeth clipping and tail docking), lack of opportunity for rooting and 
for sows to build a nest or wean their piglets gradually (Voiceless 2005; see also Scientific Veterinary Committee of the European Union 1997). They also criticized the profit-driven "factory" farming businesses dominating pig production. For example, the first report by Voiceless on pig welfare in Australia was titled "From Paddocks to Prisons" (Voiceless 2005) and framed as an indictment against "factory farming". The report urged "banning factory farms" in favor of small-scale free range "family" farms. Similarly, Animals Australia's (2012) long running "Make it Possible" campaign has the tagline "imagine a world without factory farming...”.

Australian consumers are also concerned about the welfare of pigs in intensive production systems. Cornish and colleagues (2019) surveyed Australian consumers and found that an overwhelming majority were concerned about the welfare of pigs, hens and chickens, and $(63 \%)$ believed there were insufficient high welfare pork products available to purchase. ${ }^{13}$ International studies of consumer perceptions of animal welfare have found that consumer perceptions are strongly connected to the idea of animals living in "natural" environments, where they are able to express "natural" behaviors (Spooner et al., 2014; Krystallis et al., 2009). Thorslund and colleagues (2017: 39-40) found that EU consumers connected the idea of pigs expressing natural behaviors with pigs that have access to the outdoors and are "freeranging and not being intensively reared".

The main focus of animal activism in relation to pigs, however, became the goal of freeing sows from particular forms of confinement (Voiceless 2012, 2013; Animals Australia 2012). Thus in 2012 and 2013, Voiceless published a briefing and report on pig welfare entitled "Science and Sense: The Case for Abolishing Sow Stalls" with a cover image of a sow's sad face behind bars. Despite the broader campaign goal of ending factory farming, animal protection organizations in Australia have generally adopted a pragmatic "incrementalist" 
approach to their campaigning (Chen 2016: 155). In order to mobilize consumers through the actions of the major supermarkets (Parker et al. 2019), animal advocacy groups needed to frame the issue in a way that resonated with both groups of stakeholders. As Holzer (2006) emphasizes, appropriate framing of issues is critical for social movements. Framing pig welfare in terms of freeing sows from stalls (accompanied by images of sows behind bars) provides a strong emotional appeal to the general public, as Elzen et al. (2011) emphasize in their case study of pig welfare campaigns in the Netherlands in the 1980's to 1990's. This framing of the pig welfare problem also provides a clear "ask" of government and corporates. Moreover, a well-accepted alternative technology (group pens for sows) already existed. Legislated responses to normative pressure for improved pig welfare in the EU had already accommodated public concerns in a way that minimized impacts on the existing model of intensive pig meat production through a partial ban on sow stalls. This combination of a clear ask on a single issue from the animal welfare movement and the availability of a minimally disruptive alternative technology facilitated industry co-optation of animal welfare concerns, as we show below.

Parliamentary bills to ban sow stalls were introduced by the Australian Greens in several states of Australia from 2011 (Faruqi 2014; Victorian Greens 2014), but were defeated, with the exception of two small states with very little pig production. ${ }^{14}$ Nevertheless, the pressure created by continued activism from animal welfare groups demanded a shift in production practices (King and Busa 2017). Normative pressure for change also increased as a result of an "external shock" (Elzen et al. 2011). In November 2009, the commercial current affairs TV program 60 Minutes aired an expose of an intensive pig farm, using Animals Australia footage of sows in stalls (Australian Communications and Media Authority 2010). This raised public awareness and pushed the issue up the policy agenda for both supermarkets and 
the pig industry. Animal welfare groups had opened a "policy window" (Kingdon 2010), creating new norms (King and Busa 2017), even if only temporarily, and a new market opportunity for industry buy-in.

\subsection{The Market-Led Creation of Sow Stall Free}

Key industry actors began positioning themselves to respond to this opportunity. In 2007, one of Australia's largest producers, Riverlea, committed to phase out sow stalls, in consultation with one of the nation's two largest retailers, Woolworths (Locke 2010). Australia's other major national retailer, Coles, then announced in 2010 that it would phase out the use of sow stalls for own brand fresh pork products, citing consumer concerns (Eckersley 2010). Coles is an extremely powerful actor within the regulatory space, as a result of the very high level of corporate concentration in the Australian food retail market (Arup et al. 2017). Coles therefore has significant capacity to set the rules for other industry actors. APL initially pushed back at Coles' announcement that it would stop sourcing products from sow stall systems, claiming that Australian producers would be disadvantaged, particularly by imports of processed pig meat products (Farmers Weekly 2010). ${ }^{15}$

However, Coles had a response: The earlier regulatory action taken in the EU to (partially) ban sow stalls suggested that it would be possible for Australian farmers to adapt to the new requirements. Action in the EU had hastened the development of indoor group housing as an alternative to sow stalls, and new technologies and management systems had helped EU producers to overcome issues with managing individual feeding of sows in group housing systems (Elzen et al 2011). The EU regulations had also created a supply of sow stall free pig meat that could be imported into Australia for processed pig meat products. Within 6 months 
of its initial announcement, Coles expanded sourcing under its "sow stall free" standard to include processed products, such as ham and bacon (Dunlevy, 2010).

Animal welfare developments in other intensive animal industries in Australia also strengthened the conditions for industry buy-in and co-optation. The egg and meat chicken industries had been embroiled in ongoing controversies about poor animal welfare and criticism of industry responses (Carey, Parker, and Scrinis 2017; Parker et al. 2017; Parker, Carey, and Scrinis 2018). This created a backdrop for the Australian pig industry to learn from the experiences of the poultry industries and swiftly adopt a more proactive approach to addressing the growing concerns of consumers and retailers. Within months of Coles' announcement, APL announced its own voluntary industry phase out of sow stalls by 2017 (AAP 2010). APL stated that it "did not believe the community would accept the use of sow stalls on an ongoing basis" (Commonwealth of Australia 2012, 140) and that it needed to "show leadership by setting the agenda and ensuring our social license to operate" (APL 2011, 6).

\section{[INSERT FIGURE 1]}

By the beginning of 2013 (see Figure 1), twelve months ahead of schedule, Coles announced that it had eliminated sow stalls from the production of own brand pork products, and products labelled "sow stall free" appeared on the supermarket's shelves (Long 2013). Australia's other major retailer, Woolworths, also bought into "sow stall free", accrediting its products under APL's sow stall free standard (Woolworths Group 2020). This standard is slightly different to the Coles standard (as shown in Table 2 and discussed further below). Within four years, $80 \%$ of the Australian sow herd was "sow stall free" according to APL 
(2017). As the next section shows, this was not as big a victory for animal advocates as the term "sow stall free" suggests.

\subsection{Industry co-optation: a reductionist and over-simplified response}

There are three main ways in which "sow stall free" production and labelling in Australia is a reductionist and over-simplified response to animal welfare issues in intensive pig farming. This represents, in King and Busa's (2017) terms, a form of industry co-optation.

Firstly, "sow stall free" is an example of "housing reductionism" in animal welfare labelling (Scrinis et al. 2017), similar to the reductionism inherent in the use of the term "free range" in relation to layer hens. Just as "free range" labelling of eggs tells the consumer only that the hen had an opportunity to go outside, but nothing about other aspects of the hen's health and wellbeing (Scrinis et al 2017), "sow stall free" tells the consumer only about the sow's housing and fails to inform consumers about her basic health and functioning (e.g., freedom from disease and injury), her affective state (e.g., experience of pleasure and pain) and her freedom to express natural behaviors, such as nest building and rooting for food (Fraser 2008). ${ }^{16}$ Other higher welfare standards for pigs focus more broadly on a range of improvements as illustrated in Table 2, yet the focus on "sow stall free" largely ignores these other dimensions of pig welfare.

Secondly, "sow stall free" focuses attention only on the welfare of the sow (the mother pig) rather than her offspring, the piglets that are consumed as meat. The piglets (or grower pigs) do not necessarily experience many improvements in animal welfare as a result of the introduction of "sow stall free". As Table 2 shows, piglets in intensive production systems were already raised in group pens in sheds (APL 2018), and "sow stall free" gives them few additional housing benefits. ${ }^{17}$ Moreover piglets in intensive production systems may also be 
subject to a number of painful procedures in the first few days of their lives, including castration, tail docking and teeth clipping (European Food Safety Authority 2007; RSPCA 2017). While the Coles "sow stall free" accreditation system prohibits some of these additional procedures, the APL system does not (although Woolworths prohibits some procedures for own brand products). ${ }^{18}$ More importantly, the piglets consumed as meat are not referenced by the term "sow stall free", despite its heavy marketing by Coles. Fine print on the packet itself and on Coles and Woolworths websites sometimes indicates that it is the breeder pig (the mother pig), not the piglet, who is "sow stall free". However, consumers may not understand that the term does not apply to the meat product advertised. The term "sow stall free" reinforces the "absent referent" of the piglet to be consumed (Adams 1990). ${ }^{19}$ Hence, the term is arguably misleading.

Thirdly, sow stall free focuses on freeing sows from only one form of confinement, but not from all forms, thus simplifying "higher welfare" into a single technology change. Sows in intensive production systems experience three main forms of confinement during the breeding cycle: mating stalls, sow stalls and farrowing crates (APL 2018c). Sows are mated in "mating stalls", which are similar to sow stalls, ${ }^{20}$ where they will remain for one to five days until the pregnancy is established (see Table 2). ${ }^{21}$ Once they leave the mating stall, sows in conventional production systems in Australia move to a sow stall, where they can spend a maximum of six weeks under the Model Code (Primary Industries Standing Committee 2008). Sows in "sow stall free" production systems will move to indoor group housing instead of a sow stall. However, around a week before they give birth, sows in both conventional and sow stall free systems move to a "farrowing crate", where they will remain until the piglets are weaned at around three to five weeks. Farrowing crates were introduced in the 1960's to prevent piglets being crushed by mother pigs and to improve the efficiency 
of sow management. They are similar to sow stalls, but have room for piglets alongside their mothers (Baxter, Lawrence, and Edwards 2012). Sows in farrowing crates may experience similar welfare issues to confinement in sow stalls and are unable to express natural birthing behaviors such as nest building (Farm Animal Welfare Committee 2015).

The use of farrowing crates is prohibited in the system of indoor pig meat production accredited by the respected Australian animal welfare group the RSPCA (2018). A number of US companies have also committed to phase out both sow stalls and farrowing crates, including the high end US supermarket Wholefoods, which accredits its pork products under an accreditation system that prohibits farrowing crates (the Global Animal Partnership). ${ }^{22}$ The replacement for farrowing crates is often indoor "free farrowing" systems (pens big enough to allow the sow to turn around with a bar to protect piglets). However, these systems have not had significant take up in commercial pig farming to date, due to concerns about piglet mortality rates, greater space requirements, increased cost and added complexities of animal management (Baxter, Lawrence, and Edwards 2012; Marchant et al. 2000). Although retailers and the pig industry are coming under increasing pressure to remove farrowing crates, the technology stream (Elzen et al. 2011) has not yet provided an alternative that has widespread acceptance, and the pig meat industry has not yet found a way to corporatize this demand of the animal welfare movement to fit the industrial model of pig meat production. The "sow stall free" version of higher welfare production best lends itself to the existing industrial model of pig meat production favored by the major supermarkets and the pork industry, and thus it is this system that has been taken up.

The use of the word "free" in "sow stall free" is misleading as sows still spend a large part of their lives in the confinement of mating stalls and farrowing crates. They do not free range in outdoor systems where they have opportunities to express natural behaviors, such as 
wallowing, rooting and foraging for food (Scientific Veterinary Committee of the European Union 1997). Other higher welfare systems that would give sows and piglets more freedom than "sow stall free" are difficult to scale up for intensive farming. The Australian "outdoor bred (raised indoors on straw)" and "free range" production systems summarized in Table 2 both require breeding animals (sows and boars) to live their lives outdoors as "free range" animals (APL 2018a and 2018b). Piglets also have outdoor access in free range systems (APL 2017; RSPCA 2018). However, only 5\% of pigs are raised in free range systems in Australia (APL 2018a) due to significant economic, environmental and climate constraints. Pigs are sensitive to heat (CIWF 2006), they cause damage to vegetation and soils through foraging and rooting behavior (Edge et al. 2005; Bondi et al., 2015), and excess nutrients from manure can leach into land and water systems (Siegford 2008). However, there is ongoing social movement activism in Australia for further improvements to pig welfare beyond "sow stall free". These "response movements" (King and Busa 2017) are a source of contestation and they open up the possibility for further improvements to animal welfare.

\subsection{Response movement and contestation: The battle for the meaning of sow stall free}

King and Busa (2017) argue that when industry co-opts social movement activism, response movements emerge that critique the co-optation and work to achieve alternative solutions, including government regulation of business practices. The response movement includes animal welfare groups (Animals Australia 2012; Voiceless 2015; RSPCA 2017) and minor political parties, such as the Australian Greens (Victorian Greens 2014), who continue to advocate for a regulatory ban on all forms of confinement for sows and, indeed, for the abolition of animal factory farming. There are also niche industry responses to concerns about factory farming of pigs such as "outdoor bred (raised indoors on straw)" and "free range", both of which free sows from all forms of confinement (as discussed above). ${ }^{23}$ 
Moreover, there is on-going contestation about "sow stall free" among corporate actors. As described above, two competing definitions of "sow stall free" have emerged in the Australian marketplace (see Table 2): the APL standard, which has been adopted by the supermarket chain Woolworths for its own brand pig meat products and a bespoke "sow stall free" standard developed by the retailer Coles, which is also administered by the APL accreditor. Products accredited under the Coles "sow stall free" standard display a "sow stall free" label, while those accredited under the APL industry definition of "sow stall free" do not. Animal activists argue that the term "sow stall free" is highly misleading, given that both sows and piglets in these production systems still experience multiple forms of confinement (e.g., Voiceless 2015). The absence of a "sow stall free" claim on the labelling of products accredited under the looser industry standard suggests that Woolworths (and other retailers using the standard) believe that the ACCC would regard the claim as misleading and deceptive. In 2013, the ACCC reportedly asked APL to correct its claim that it was "phasing out" the use of sow stalls (Voiceless 2013). APL then introduced the following qualifier to its use of the term "gestation stall free":

"This means that a sow will only spend up to 5 days in a mating stall, to stabilize pregnancy and then later be moved into a farrowing crate or birthing stall, up to a week before she is due to give birth. In this way, Australia's pregnant sows only spend a maximum of 10 per cent of their total pregnancy ${ }^{24}$ individually confined under the gestation stall free definition." (APL 2013,1)

This qualification is not, however, evident in the way the term "sow stall free" is used for mass consumption in Coles supermarkets. 


\subsection{Influence on future mandatory regulatory standards}

The Model Codes of Practice that set the standards for farm animal welfare in Australia are being replaced by Australian Animal Welfare Standards and Guidelines that will form the legal requirements for animal welfare across Australian states and territories (Animal Health Australia 2017). In 2016, APL asked the Agriculture Senior Officials Committee (AGSOC), ${ }^{25}$ an inter-jurisdictional group of senior agriculture bureaucrats, to bring forward the development of the new Animal Welfare Standards and Guidelines for Pigs (APL 2017b) and called for the industry's voluntary phase out of sow stalls to become mandatory in the new standards (Locke 2016). AGSOC agreed and asked APL to put forward a business plan for development of the standards and guidelines, including terms of reference for a "science review" to underpin their development. In mid-2017, APL commissioned this review (APL 2017b), and expects that the new standards and guidelines will "include a mandatory sow stall use condition that matches up with the industry's voluntary initiative" (APL 2017a).

There are two reasons why it may now be in the interests of the mainstream pork industry in Australia (represented by APL) to support mandatory regulation. First, it is in the interests of sow stall free adopters to ensure that non-adopters are obligated to comply. This dynamic, in which early adopters of new responsibilities advocate for regulatory institutionalization of those responsibilities to ensure a level playing field, is a time honored mechanism for the creation of new regulation (Ogus 1994: 71-2).

Second, it is also in the interests of the pork industry to proactively promote mandatory standards that institutionalize their own version of "sow stall free", rather than competing versions proposed by supermarkets or animal advocacy groups. Coles has been the dominant force to date in setting the rules for "sow stall free" in the regulatory space. It was the first key stakeholder in the field to "corporatize" (King and Busa 2017) the movement to free 
sows from stalls in a way that allowed mass participation in the movement. APL then introduced a weaker definition. The development of new government regulation may now offer APL an opportunity to embed its definition of higher pig welfare in the market through mandatory regulation, analogous to how industrialized organic standards have been enshrined in regulation in the US (see Haedicke 2016; Guthman 2004).

APL's ability to influence the development of the standards and guidelines is enabled by the close relationship that exists between industry and government agriculture departments in Australia in the governance of animal welfare. The development of two other sets of Animal Welfare Standards and Guidelines (for poultry and for land transport) have been widely criticized for the dominance of industry influence in the process, which is managed by Animal Health Australia (a public private partnership whose members include APL, the peak bodies of livestock industries and government representatives) (see Goodfellow 2016; White 2013; Parker et al. 2018). The livestock industries are not only able to exert influence over the development of the standards, but also over the scientific research that underpins the standards (White 2013). Indeed, they may even be involved in commissioning the research, as is the case in the development of the standards and guidelines for the welfare of pigs. By leveraging this close relationship with Animal Health Australia and government departments of agriculture, APL has the potential to counter the significant power of Coles in the regulatory space to shift the meaning of "sow stall free" in line with its own preferred definition. The market-based standards established for free range eggs in Australia were similarly weakened by the development of a national information standard for free range eggs in 2016-17 (Carey, Parker, and Scrinis 2017).

The new pig welfare standards are also likely to be subject to ongoing contestation. As King and Busa $(2017,558)$ point out in the case of the organic food movement, "while standards 
and regulations weakened the progressive side of the organic movement in some ways, corporatization may have served to energize the non-corporatized movement as new organizations have formed in opposition to the industrialized version of organic and sought to draw attention back to some of the ideals of the 1960s" (citing Guthman 2004). Similarly, in pig production, the animal movements continue to advocate for further welfare measures (Voiceless 2015; RSPCA 2017). There are also new alternative food producer associations (e.g., Australian Food Sovereignty Alliance 2019) and celebrity chefs (Evans 2019, 151-164) that seek to alert farmers and consumers to a broader range of welfare (and ecological) issues that challenge the mainstream pork industry. The social movement for animal advocacy also remains active. Normative pressure is likely to continue to build to free sows from farrowing crates. Farrowing crates have been banned in Switzerland, Sweden and Norway (Farm Animal Welfare Committee 2015), and Coles has signaled to producers its intention to phase them out for its suppliers in Australia (Dunlevy 2010). Such a move is likely to be strongly resisted by the pig industry unless and until a new technology stream develops that leads to more widespread acceptance of "free farrowing" alternatives (Elzen et al 2011).

\section{Discussion and conclusion}

There is growing public concern in Australia, as in many other regions of the world, about the welfare of pigs in intensive "factory farming" systems. The responses to social movement activism about pig welfare have included government regulation in regions such as the EU (European Commission 2008) and Canada (Canadian Pork Council and National Farm Animal Care Council 2014) and market-based responses, as in our Australian case study. Both types of response have focused on freeing sows from sow stalls, one of three forms of confinement used during the breeding cycle. 
By "backwards mapping" (Parker, 2014) the higher welfare pig meat products that are available in the Australian marketplace and the governance of the production practices behind them, we have shown how "sow stall free" emerged in Australia. The relevant factors included government failure to regulate to improve pig welfare (King and Busa 2017), and the activism of Australian animal welfare groups (e.g., Voiceless 2013) that campaigned against factory farming of pigs with a particular focus on sow stalls as an achievable reform.

The introduction of "sow stall free" was also influenced by the introduction of regulation to partially ban sow stalls in the EU (European Commission 2008 ), which created a supply of "sow stall free" pig meat for imports of processed pork to Australia, and by technological innovation (Elzen et al. 2011), which created an alternative to sow stalls in the form of group housing. This was the obverse of the "Brussels effect", where the desire to export to the lucrative European market nudges multinational companies based outside the EU to produce goods that meet higher EU standards and sell them throughout the world (Bradford 2012). In this case, a similar globalization of the higher European regulatory standards occurred through a complementary market mechanism. The higher regulatory standards for pig welfare in the EU created an alternative source of supply for the two major Australian supermarkets, who wanted to impose higher standards on producers in order to appeal to consumers. Australian pork producers had little choice but to fall into line or lose their main market. In this case, the greater appetite of European citizens and governments for high animal welfare regulation was globalized to Australia.

Lastly, the emergence of sow stall free labelling was influenced by the very high level of supermarket concentration in the Australian retail sector, which enabled Coles supermarkets to initially set the rules of the game with its decision to respond to normative pressure by sourcing own brand pork products from "sow stall free" production systems. We have argued 
that these factors created the conditions in which a simplified and scaled up response to animal activism against factory farming of pigs was possible. That is, Australian "sow stall free" represents a "corporatized" or "co-opted" form of market-based animal welfare protection.

The industry body APL has now called for national regulation to ban sow stalls (Locke 2016) in line with its own (arguably misleading) version of "sow stall free". This case highlights the centrality of regulatory institutions to capitalism (Levi-Faur 2017). The emergence of "sow stall free" is a diluted, and we argue industry co-opted, response to social movement activism to end factory farming. "Sow stall free" nonetheless represents a small incremental shift in the market, one which is likely to be formalised in regulation. One way of commodifying sows is taken out of circulation (i.e. use of sow stalls for much of their pregnancy), and the pork industry is itself now advocating for mandatory "sow stall free" standards.

Recent empirical research has also shown that adoption of animal welfare practices (such as cage free eggs) by high profile corporations (such as McDonalds) helps to create citizen support for legislation mandating those practices (Dana and Nadler 2019). Thus, the adoption of "sow stall free" by supermarkets and industry may have created a small foothold for collective agreement amongst industry, animal groups and the wider public about the need for welfare protections for sows in relation to sow stalls. As Dana and Nadler $(2019,83)$ note, further research is needed in order to elaborate the conditions under which small incremental changes, such as those represented by the introduction of "sow stall free", can "lock in" the possibility of collective support for further regulatory reform on public interest grounds, and when market-led voluntary reforms "crowd out" the potential for further regulatory reform. 
An incremental reform like "sow stall free" represents a real, albeit limited, success for social movement groups in contesting the boundaries of commodification. Yet the pork industry and supermarket retailers have been able to use this one small incremental reform to corporatize the very concept of animal welfare within the dominant factory farming of pigs for meat, thus maintaining a largely commodified version of animals. In line with the Polanyi-an roots of regulatory capitalism theory (Polanyi 2001/1944), our findings reaffirm that states, social movements and businesses all interact to produce regulations that in turn shape markets. Capitalism indeed feeds on this process of commodification, contestation and recommodification. This means that there will no doubt be further contestation of other components of factory farming of pigs and further attempts to commodify animals (e.g. through new gene editing techniques), farming systems (e.g. through new smart automated shed technologies) and consumers themselves (e.g. through advertising targeted at each consumer's particular concerns). 


\section{Figures and tables}

\section{Figure 1}

Figure 1: Key developments in the governance of sow stalls 2001-2016

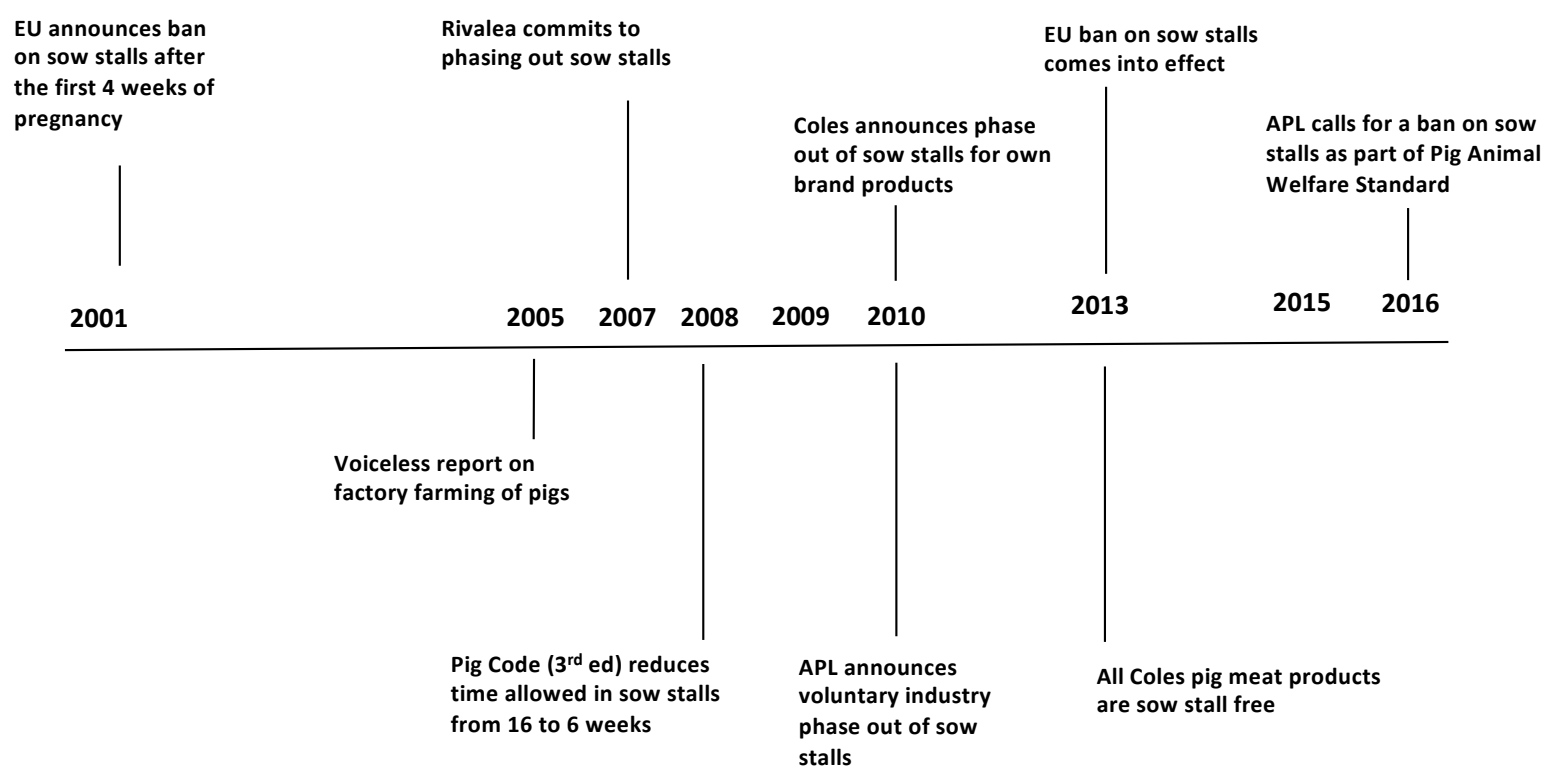


Table 1: Summary of private "sow stall free standards" in Australia compared with government regulation, selected alternative higher welfare accreditation claims in Australia, and EU regulation

\begin{tabular}{|c|c|c|c|c|c|}
\hline Standard & $\begin{array}{l}\text { Auspices and } \\
\text { Accreditation }\end{array}$ & $\begin{array}{l}\text { Sows: } \\
\text { Mating Stall }{ }^{1} \text { and } \\
\text { Sow Stall }^{2}\end{array}$ & $\begin{array}{l}\text { Sows: } \\
\text { Farrowing crates }\end{array}$ & $\begin{array}{l}\text { Piglets: } \\
\text { Castration, tail } \\
\text { docking, teeth } \\
\text { trimming }\end{array}$ & $\begin{array}{l}\text { Piglets: } \\
\text { Housing }\end{array}$ \\
\hline $\begin{array}{l}\text { Australian } \\
\text { Government } \\
\text { mandatory } \\
\text { regulation }\end{array}$ & $\begin{array}{l}\text { Model code adopted } \\
\text { by state legislation } \\
\text { and monitored and } \\
\text { enforced by state } \\
\text { departments of } \\
\text { agriculture and } \\
\text { Australian Pork } \\
\text { Industry Quality } \\
\text { Assurance (APIQ) }\end{array}$ & $\begin{array}{l}\text { Mating stall (1 week) } \\
\text { Up to } 6 \text { weeks in sow } \\
\text { stall }\end{array}$ & $\begin{array}{l}\text { Allowed }-1 \text { week } \\
\text { before giving birth } \\
\text { plus } 4 \text { weeks until } \\
\text { weaning of piglets }\end{array}$ & Allowed & $\begin{array}{l}\text { Group housing } \\
\text { indoors is normal - no } \\
\text { requirement for } \\
\text { enrichment. }\end{array}$ \\
\hline $\begin{array}{l}\text { Coles - Sow Stall } \\
\text { Free }\end{array}$ & $\begin{array}{l}\begin{array}{l}\text { Coles version of } \\
\text { certification scheme } \\
\text { operated by APIQ }\end{array} \\
\text { Labelled and heavily } \\
\text { marketed by Coles }\end{array}$ & $\begin{array}{l}\text { Mating stall - up to } \\
\mathbf{2 4} \text { hours after } \\
\text { mating to establish } \\
\text { pregnancy } \\
\text { Then in "loose } \\
\text { housing" with space to } \\
\text { move around for most } \\
\text { of pregnancy. Bedding }\end{array}$ & $\begin{array}{l}\text { Allowed as above. } \\
\text { Bedding materials } \\
\text { required }\end{array}$ & $\begin{array}{l}\text { Piglets cannot } \\
\text { routinely be } \\
\text { castrated, have } \\
\text { their tails docked } \\
\text { or teeth trimmed. }\end{array}$ & $\begin{array}{l}\text { Group housing } \\
\text { indoors with } \\
\text { minimum space } \\
\text { requirement - no } \\
\text { requirement for } \\
\text { enrichment. }\end{array}$ \\
\hline
\end{tabular}

${ }^{1}$ According to Australian Pork Ltd all sows are put in mating stall after weaning for approximately 5 days before mating until they come on heat. They are then kept in the mating stall for between 1 and 5 days to ensure the pregnancy implants. See http://australianpork.com.au/industry-focus/animal-welfare/housing/ Mating is often via artificial insemination.

2 Also known as a "gestation stall" or "crate". Pregnancy is typically 16 weeks.

${ }^{3}$ Also known as "piglet protection pens". 


\begin{tabular}{|c|c|c|c|c|c|}
\hline & & $\begin{array}{l}\text { materials mandatory } \\
\text { from } 2020 \text {. }\end{array}$ & & & \\
\hline $\begin{array}{l}\text { APL, Woolworths } \\
\text { and other } \\
\text { retailers - Sow } \\
\text { Stall Free }\end{array}$ & $\begin{array}{l}\text { APIQ } \\
\text { Not labelled; quietly } \\
\text { marketed by } \\
\text { Woolworths via } \\
\text { website }\end{array}$ & $\begin{array}{l}\text { Mating stall - up to } 5 \\
\text { days after mating to } \\
\text { establish pregnancy } \\
\text { Then in "loose } \\
\text { housing" with space to } \\
\text { move around for most } \\
\text { of pregnancy. }\end{array}$ & $\begin{array}{l}\text { Allowed as above. } \\
\text { No bedding materials. }\end{array}$ & $\begin{array}{l}\text { Allowed under } \\
\text { APL standard. } \\
\text { Tail clipping and } \\
\text { castration } \\
\text { prohibited for } \\
\text { Woolworths own } \\
\text { brand products. }\end{array}$ & $\begin{array}{l}\text { Group housing } \\
\text { indoors - no } \\
\text { requirements for } \\
\text { enrichment. }\end{array}$ \\
\hline $\begin{array}{l}\text { APL - Outdoor } \\
\text { bred, raised } \\
\text { indoors on straw }\end{array}$ & $\begin{array}{l}\text { APIQ } \\
\text { Labelled by brands } \\
\text { that produce them }\end{array}$ & $\begin{array}{l}\text { Mating stall - up to } 5 \\
\text { days after mating to } \\
\text { establish pregnancy } \\
\text { Then free range with } \\
\text { hut for shelter } \\
\text { paddock and } \\
\text { wallows/shade where } \\
\text { possible. }\end{array}$ & $\begin{array}{l}\text { Prohibited - free range } \\
\text { with hut for shelter. }\end{array}$ & Prohibited & $\begin{array}{l}\text { Group housing } \\
\text { indoors or in } \\
\text { 'ecoshelters'- must } \\
\text { have bedding. }\end{array}$ \\
\hline $\begin{array}{l}\text { RSPCA Approved } \\
\text { (Outdoor) } 6 \\
\text { Coles Free Range }\end{array}$ & $\begin{array}{l}\text { RSPCA - highly } \\
\text { respected animal } \\
\text { welfare agency } \\
\text { which regularly } \\
\text { monitors } \\
\text { compliance. }\end{array}$ & $\begin{array}{l}\text { Mating pens must be } \\
\text { a minimum of } 10.5 \\
\mathbf{m}^{2} \text { and should allow } \\
\text { the sow and boar to } \\
\text { turn around. } \\
\text { Then free range with } \\
\text { hut, which must }\end{array}$ & $\begin{array}{l}\text { Prohibited - free range } \\
\text { with hut which must } \\
\text { include bedding and } \\
\text { wallow. }\end{array}$ & Prohibited & $\begin{array}{l}\text { Free range with hut } \\
\text { which must include } \\
\text { bedding and wallow. }\end{array}$ \\
\hline
\end{tabular}

${ }^{4}$ Industry documents suggest that some sows may spend additional time in mating stalls before mating, while they come on heat. It is unclear how much additional time sows may spend in stalls while on heat or how many sows this applies to.

${ }^{5}$ Also known as 'Outdoor bred, raised on straw in shelters', previously known as 'Bred free range'.

${ }^{6}$ RSPCA also approves indoor only production systems. These standards are not included here. 


\begin{tabular}{|c|c|c|c|c|c|}
\hline & $\begin{array}{l}\text { Labelled by Coles - } \\
\text { but very small } \\
\text { proportion of market }\end{array}$ & $\begin{array}{l}\text { include bedding and } \\
\text { wallow. }\end{array}$ & & & \\
\hline $\begin{array}{l}\text { APL Certified } \\
\text { Free Range and } \\
\text { Woolworths Free } \\
\text { Range }\end{array}$ & $\begin{array}{l}\text { APIQ } \\
\text { Labelled by } \\
\text { Woolworths - but } \\
\text { very small } \\
\text { proportion of market }\end{array}$ & 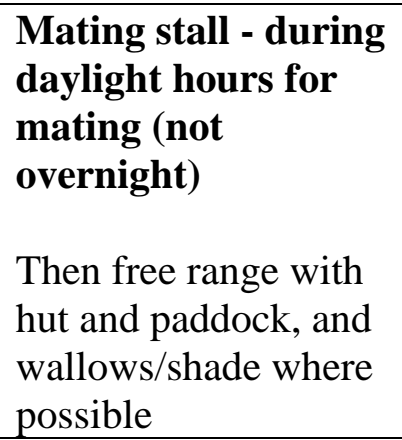 & $\begin{array}{l}\text { Prohibited - free range } \\
\text { with hut, access to } \\
\text { paddock and } \\
\text { wallows/shade where } \\
\text { possible. }\end{array}$ & Prohibited & $\begin{array}{l}\text { Free range with hut } \\
\text { and paddock, and } \\
\text { wallows/shade where } \\
\text { possible. }\end{array}$ \\
\hline EU Regulation & $\begin{array}{l}\text { Must be } \\
\text { implemented by } \\
\text { individual nation- } \\
\text { states. } \\
\text { Implementation and } \\
\text { enforcement patchy } \\
\text { and weak. }\end{array}$ & Up to 4 weeks ${ }^{7}$ & Allowed & $\begin{array}{l}\text { Routine castration } \\
\text { and tail docking } \\
\text { not allowed, Teeth } \\
\text { clipping allowed } \\
\text { before } 7 \text { days of } \\
\text { age. }\end{array}$ & $\begin{array}{l}\text { Group housing } \\
\text { indoors - must have } \\
\text { access to manipulable } \\
\text { material. } \\
\text { May be free range. }\end{array}$ \\
\hline $\begin{array}{l}\text { Sow stall ban in } \\
\text { Massachusetts } \\
\text { (US) from } 2022\end{array}$ & $\begin{array}{l}\text { To be implemented } \\
\text { and enforced by } \\
\text { Department of } \\
\text { Agriculture }\end{array}$ & $\begin{array}{l}\text { Not allowed - only } 6 \\
\text { hours within } 24 \text {-hour } \\
\text { period for animal } \\
\text { husbandry }\end{array}$ & $\begin{array}{l}\text { Allowed - } 5 \text { days } \\
\text { before farrowing plus } \\
\text { farrowing period }\end{array}$ & Not addressed & Not addressed \\
\hline
\end{tabular}

${ }^{7}$ Sow stalls are completely banned in the UK and Sweden. 


\section{NOTES}

${ }^{1}$ As discussed below, sow stalls are completely banned in the UK and Sweden and can only be used for part of the pregnancy in the rest of the EU, New Zealand and some US states. They are being phased out via legislation in Canada, and a number of other US states.

${ }^{2}$ APL is a producer-owned company formed in May 2000. It acts as a peak body for the industry, and also has a marketing and research and development role supported by government and funded by industry contributions (Acil Allen, 2014).

${ }^{3}$ Note that legal definitions of food labels include all the tags, brands, marks, statements, representations, designs and descriptions on food and its packaging and made or displayed to consumers when it is sold: Standard 1.1.2 of Australia New Zealand Food Standards Code; Codex Alimentarius, CODEX STAN 1-1985[2] (Rev. 1-1991).

${ }^{4}$ Compassion in World Farming tabled a petition in the European Parliament in 1991, calling for animals to be recognised as sentient beings. This was initially recognised as a non-binding Treaty Declaration, before being given legal status in 1997 as a Protocol attached to the Treaty of Amsterdam. In 2009, animal sentience was recognised as an Article in the Lisbon Treaty, giving it additional weight within the EU (Compassion in World Farming 2009).

${ }^{5}$ Sweden had already taken regulatory action to ban sow stalls in 1988 (European Parliament 2013).

${ }^{6}$ EU Council Directive 2008/120/EC.

${ }^{7}$ Sow stalls have been banned in Arizona, California, Colorado, Florida, Maine, Massachusetts, Michigan, Ohio, Oregon, Rhode Island, mostly as a result of social movement activism prompting referendum resolutions. See https://www.aspca.org/animal-protection/public-policy/farm-animal-confinement-bans

${ }^{8}$ Note however that the EU has faced difficulties with enforcing compliance among member states. See http://www.thepigsite.com/swinenews/38788/eu-countries-still-not-complying-with-sow-stall-ban-after-twoyears/ and https://www.ciwf.org.uk/news/2014/01/six-countries-still-flouting-sow-stall-ban

${ }^{9}$ Voluntary company commitments to remove gestation crates and bans in some states of the US typically allow some time in a crate, as in Australia.

${ }^{10}$ The Model Codes of Practice for other farmed animals in Australia exist as voluntary codes rather than legislated standards.

${ }^{11}$ We visited twenty-seven stores in total in different areas of Melbourne (representing a range of socioeconomic characteristics) between April and December 2015. We focused on three types of fresh pig meat products (pork leg roast, pork steaks/fillets and pork cutlets/chops) and two types of processed pork products (ham and bacon). Most pig meat (around 60\%) is consumed in Australia as processed products (Meat and Livestock Australia 2010). While all of the fresh pork consumed in Australia is produced in the country (fresh pork cannot be imported to Australia), around $70-80 \%$ of the processed pig meat consumed is imported (DEDJTR 2014). At each store, we took photos of the products available and the shelf displays for these products. We also collected data about the animal welfare claims made on these products, accreditations displayed, images and symbols used to communicate ethical values associated with production practices and the price of the product per 100g. For more details see Parker, Carey, and Scrinis (2018a).

12 The Australian Greens is a political party with its roots in the environment movement.

${ }^{13}$ But note that the survey was based on a convenience sample.

${ }^{14}$ The Australian Capital Territory banned sow stalls in 2014 but has no intensive piggeries (Lawson 2014). Tasmania (Department of Primary Industries, Parks, Water and Environment 2018) also introduced a partial ban on sow stalls from 2013 (sow stalls can only be legally used in Tasmania for 10 days) (Primary Industries Standing Committee 2008). The value of the Tasmanian pig industry is less than $1 \%$ of the national industry (Acil Allen 2017).

${ }^{15}$ Australia's strict biosecurity regulations prevent the importation of most types of fresh meats and animal products, but around $70-80 \%$ of the processed pig meat, such as ham and bacon, consumed in Australia is imported (DEDJTR 2014).

${ }^{16}$ There is also little information provided on these other aspects of pig welfare on the Coles website.

${ }^{17}$ See Australian Pork Industry Quality Assurance Program (2019). 


\footnotetext{
${ }^{18}$ Woolworths Pork Blueprint animal welfare framework bans the use of tail clipping and surgical castration for own brand products (Woolworths Group 2020)

19 The male breeder, the boar, is also absent.

${ }^{20}$ Mating stalls are usually located in a different part of the farm to sow stalls and allow access for boars, although most sows are mated via artificial insemination (APL 2018c).

${ }^{21}$ They spend up to 1 day in a mating stall under the Coles "sow stall free" standard and up to 5 days under the industry standard used by Woolworths (Australian Pork Industry Quality Assurance Program 2017). Both standards involve considerably less time spent in a stall than the regulatory bans in the EU and Canada, which allow pigs to spend up to 4 weeks of their pregnancy in a stall (European Commission 2008; Canadian Pork Council and the National Farm Animal Care Council. 2014).

${ }^{22}$ See https://www.wholefoodsmarket.com/mission-values/animal-welfare/5-step-animal-welfare-rating. Also see Negowetti (2018) for criticisms of the monitoring and enforcement of these standards.

${ }^{23}$ Products from these alternative systems are available in the major retailers, at smaller independent retailers and at farmers markets.

${ }^{24}$ Note the weaning period spent in the farrowing stall is not mentioned.

${ }^{25}$ AGSOC comprises the department heads and CEOs of Australian state and territory departments of primary industry. It also includes representatives of the New Zealand primary industries agency (Australian Government 2014).
}

\section{References}

AAP. 2010. "No More Sow Stalls, Says Pork Industry," Sydney Morning Herald 18 November. https://www.smh.com.au/environment/conservation/no-more-sow-stalls-says-pork-industry20101118-17yon.html (accessed 18 November, 2018).

Acil Allen. 2017. Economic contribution report: pork industry in Australia 2015-16. Sydney: Acil Allen Consulting.

Acil Allen. 2014. Performance review of APL: Three year review. Sydney: Acil Allen Consulting.

Adams, C. 1990. The Sexual Politics of Meat: A Feminist-Vegetarian Critical Theory (Bloomsbury, New York).

Australian Communications and Media Authority. 2010. Investigation report 2436. Australian Communications and Media Authority

Animals Australia. 2012. Make it Possible. 12 October. http://makeitpossible.com/ (accessed 28 March 2018).

Animal Health Australia. 2017. Australian Animal Welfare Standards and Guidelines. 20 November. http://www.animalwelfarestandards.net.au/about-2/ (accessed 6 April 2018).

Arup, C., Beaton-Wells, C. and Paul-Taylor, J. 2017. Regulating supermarkets: The competition for space. UNSW Law Journal 40 (3): 1035-1071.

Australian Food Sovereignty Alliance. 2019. About the Australian Food Sovereignty Alliance. https://afsa.org.au/about/ (accessed 8 April 2019).

Australian Government. 2014. Agriculture Senior Officials Committee. https://www.directory.gov.au/portfolios/agriculture-and-water-resources/department-agriculture-andwater-resources/agriculture-senior-officials-committee (accessed 3 March 2019).

Australian Pork Industry Quality Assurance Program. 2019. APIQ Standards Manual: For Producers, Auditors and Stakeholders. Version 4.55. Canberra: Australian Pork Industry Quality Assurance Program.

Australian Pork Limited (APL). 2011. Australian Pork Ltd's Submission into the Senate Inquiry into Australia's Food Processing Sector. Canberra: Australian Pork Ltd.

Australian Pork Limited (APL). 2013. Australian Pork Ltd Annual Report 2012-13. Canberra: Australian Pork Ltd.

Australian Pork Limited (APL). 2017. Australian Pork Ltd Annual Report 2016-2017. Canberra: Australian Pork Ltd.

Australian Pork Limited (APL). 2017a. Australian Pork Ltd Annual Operating Plan Summary 2017/2018. Canberra: Australian Pork Ltd. 
Australian Pork Limited (APL). 2017b. Terms of Reference for Review and Collation of Pig Welfare Research to Inform the Development of the Australian Animal Welfare Standards and Guidelines for Pigs. Canberra: Australian Pork Ltd.

Australian Pork Limited (APL). 2018. Pigs: Our Farming Systems - Indoor System. https://aussiepigfarmers.com.au/pigs/our-farming-systems/indoor-system/ (accessed 19 March 2018).

Australian Pork Limited (APL). 2018a. Pigs: Our Farming Systems - Free Range System. https://aussiepigfarmers.com.au/pigs/our-farming-systems/free-range-system/ (accessed 30 April 2018).

Australian Pork Limited (APL). 2018b. Pigs: Our farming systems - Bred Free Range System. https://aussiepigfarmers.com.au/pigs/our-farming-systems/outdoor-bred-system/ (accessed 2 May 2018).

Australian Pork Limited (APL). 2018c. Animal Welfare - Housing. http://australianpork.com.au/industry-focus/animal-welfare/housing/ (accessed 15 May 2018).

Australian Productivity Commission. 2016. Regulation of Australian Agriculture. Canberra: Australian Government, 2016.

Ayers, Ian, and John Braithwaite. 1992. Transcending the Deregulation Debate. Oxford: Oxford University Press.

Bartley T, Koos S, Samel H, Setrini G, Summers N. 2015. Looking Behind the Label: Global industries and the Conscientious Consumer. Indiana University Press

Baxter, E. M., A. B. Lawrence, and S.A Edwards. 2012. "Alternative Farrowing Accommodation: Welfare and Economic Aspects of Existing Farrowing and Lactation Systems for Pigs," Animal 6: 96 $-117$.

Bondi, G., Peruzzi, E., Macci, C., Masciano, G. and Pistoia, A. 2015. Changes in soil organic matter associated with pig rearing: Influence of stocking densities and land gradient on forest soils in central Italy. Agriculture, Ecosystems and Environment 211: 32-42.

Bradford, Anu. 2012. The Brussels Effect. Northwestern University Law Review. 107: 1-67.

Braithwaite, John and Peter Drahos. 2000. Global Business Regulation. Cambridge: Cambridge University Press.

Canadian Pork Council and the National Farm Animal Care Council. 2014. Code of Practice for the Care and Handling of Pigs. Ottawa: Canada.

Carey, Rachel, Christine Parker, and Gyorgy Scrinis. 2017. "Capturing the Meaning of 'Free Range': The Contest Between Producers, Supermarkets and Consumers for the Higher Welfare Egg Label in Australia," Journal of Rural Studies 54: 266-275.

Cargill. 2018. Scope of Cargill's Commitment. https://www.cargill.com/meat-poultry/aw/animal-welfarecommitment (accessed 28 March 2018).

Caulfield, M. 2007. "The Law and Pig Farming," Reform 91(Summer): 22-24.

Caulfield, M. P., and H. Cambridge. 2008. "The Questionable Value of Some Science-Based 'Welfare' Assessments in Intensive Animal Farming: Sow Stalls as an Illustrative Example," Australian Veterinary Journal 86: 446-448.

Chen, Peter. 2016. Animal Welfare in Australia: Politics and Policy. Sydney: Sydney University Press.

Compassion in World Farming. 2009. The Lisbon Treaty: Recognising animal sentience. https://www.ciwf.org.uk/news/2009/12/the-lisbon-treaty-recognising-animal-sentience (accessed 1 December 2018).

Compassion in World Farming (CIWF). 2018. Project pig. https://www.ciwf.org.uk/our-campaigns/pigs/ (accessed 1 March 2019).

Compassion in World Farming (CIWF). 2006. Animal welfare aspects of good agricultural practice: pig production. Compassion in World Farming Trust.

Commonwealth of Australia. 2012. Official Committee Hansard, Rural and Regional Affairs and transport legislation committee, Estimates, 22 May 2012. Canberra: Commonwealth of Australia.

ConAgra. 2012. ConAgra Foods Supports Eliminating Gestation Stalls for Sows and Creating Traceability Systems within the Pork Supply Chain. 24 September. http://www.conagrabrands.com/news-room/news-conagra-foods-supports-eliminating-gestation- 
stalls-for-sows-and-creating-traceability-systems-within-the-pork-supply-chain-1737709 (accessed 28 March 2018).

Cornish, Amelia, Brayden Ashton, David Raubenheimer and Paul D. McGreevy. 2019. Australian Consumers' Knowledge and Concern for Animal Welfare in Food Production: Influences on Purchasing Intentions. Society \& Animals 1: 1-28.

D'Silva, Joyce. 2000. Factory Farming and Developing Countries: A Compassion in World Farming Trust Briefing. Hampshire: Compassion in World Farming Trust. http://citeseerx.ist.psu.edu/viewdoc/download?doi=10.1.1.537.4994\&rep=rep1\&type=pdf. (accessed 10 December 2018).

Dana, David A., and Janice Nadler. 2019. Regulation, Public Attitudes, and Private Governance. Journal of Empirical Legal Studies 16: 69-93.

Department of Economic Development, Jobs, Transport and Resources (DEDJTR). 2014. Pig, Goat and Deer Industry Profile. Victoria: Department of Economic Development, Jobs, Transport and Resources.

Department of Primary Industries, Parks, Water and Environment. 2018. Animal Welfare Inspections of Intensive Farms. http://dpipwe.tas.gov.au/biosecurity-tasmania/animal-biosecurity/animalwelfare/animal-welfare-inspections-of-intensive-farms (accessed 24 May 2018).

Dixon, Jane. 2002. The Changing Chicken: Chooks, Cooks and Culinary Culture. Sydney: UNSW Press.

Dunlevy, Gabrielle. 2010. "Coles Broadens Sow Stall-Free Pork," Sydney Morning Herald 8 November. http://www.smh.com.au//breaking-news-national/coles-broadens-sow-stallfree-pork-2010110817k30.html (accessed 23 March 2016).

Eberlein, Burkhard, Kenneth W. Abbott, Julia Black, Errol Meidinger and Stepan Wood. 2014. Transnational Business Governance Interactions: Conceptualization and Framework for Analysis. Regulation \& Governance 8:1-21.

Eckersley, Nicole. 2010. Coles pork to go sow stall free. Australian Food News 22 July 2010.

Edelman, Lauren B., 2017. Working Law: Courts, Corporations, and Symbolic Civil Rights. Chicago: University of Chicago Press.

Edge, H. L., Bulman, C. A. and Edwards, S. A. 2005. Alternatives to nose-ringing in outdoor sows: the provision of root crops. Applied Animal Science Behaviour 92: 15-26.

Elzen, Boelie, Frank W. Geels, Cees Leeuwis, and Barbara van Mierlo. 2011. "Normative Contestation in Transitions 'In the Making': Animal Welfare Concerns and System Innovation in Pig Husbandry," Research Policy 40: 263-275.

Evans, Matthew. 2019. On Eating Meat. Sydney: Murdoch Books.

European Commission. 2008. Council Directive 2008/120/EC on Laying Down Minimum Standards for the Protection of Pigs Granted [2008] OJ L 47.

European Parliament. 2013. Parliamentary questions: Implementation of ban on individual sow stalls, in force since 1 January 2013, in accordance with Directive 2008/120/EC on the protection of pigs. http://www.europarl.europa.eu/sides/getDoc.do?pubRef=-//EP//TEXT+WQ+E-2013000321+0+DOC+XML+V0//EN (accessed 2 March 2019).

European Food Safety Authority. 2007. "Scientific Report on the Risks Associated with Tail Biting in Pigs and Possible Means to Reduce the Need for Tail Docking Considering the Different Housing and Husbandry Systems," The EFSA Journal 611: 1-13.

Ewick, Patrcia, and Susan S. Silbey. 1998. The Common Place of Law: Stories from Everyday Life. Chicago: Univ. of Chicago Press.

Farm Animal Welfare Committee. 2015. Opinion on free farrowing systems. October 2015. London: Farm Animal Welfare Committee.

Farmers Weekly. 2010. "Coles Pork to be Sow Stall Free," Farmers Weekly 21 July. http://www.farmweekly.com.au/news/agriculture/cattle/beef/coles-pork-to-be-sow-stallfree/1891292.aspx? storypage $=0$ _accessed 9 February 2018).

Faruqi, Mehreen. 2014. Greens Launch Bill to Ban Sow Stalls and Farrowing Crates for Pigs. New South Wales Greens. 11 December. https://nsw.greens.org.au/news/nsw/greens-launch-bill-ban-sow-stallsand-farrowing-crates-pigs. (accessed 6 March 2019). 
Fligstein, Neil, and Doug McAdam. 2012. "A Political-Cultural Approach to the Problem of Strategic Action." In Rethinking Power in Organizations, Institutions, and Markets, edited by David Courpasson, Damon Golsorkhi and Jeffrey J. Sallaz. Bingley, UK: Emerald Group Publishing Limited.

Fraser, David. 2008. "Understanding animal welfare". Acta Veterinaria Scandinavica 50 (S1): 1-7.

Friedmann, Harriet. 2005. "From colonialism to green capitalism: Social movements and the emergence of food regimes." In New Directions in the Sociology of Global Development, edited by Frederick Buttel and Phillip McMichael, pp. 227-64. London: Elsevier.

Georgallis, Panayiotis. 2017. The link between social movements and corporate social initiatives: Towards a Multi-level theory. Journal of Business Ethics 142: 735-751.

Goodfellow, Jed. 2016. "Regulatory Capture and the Welfare of Farm Animals in Australia," In Animal Law and Welfare - International Perspectives, edited by Deborah Cao and Steven White. Switzerland: Springer International Publishing.

Guest, Greg, Kathleen M. McQueen, and Emily Namey. 2012. Applied Thematic Analysis. Thousand Oaks, CA: Sage.

Guthman, Julie. 2004. Agrarian Dreams: The Paradox of Organic Farming in California. Berkeley, CA: Univ of California Press.

Haedicke, Michael A. 2016. Organizing Organic: Conflict and Compromise in an Emerging Market. Redwood City, CA: Stanford University Press.

Hancher, Leigh, and Michael Moran. 1998. "Organizing Regulatory Space.” In A Reader on Regulation, edited by Robert Baldwin, Colin Scott, Christopher Hood. Oxford Scholarship Online.

Harlieb, Susanne, and Bryn Jones. 2009. "Humanising Business Through Ethical Labelling: Progress and Paradoxes in the UK," Journal of Business Ethics 88: 583-600.

Harrison, Ruth. 1964. Animal Machines. Walligford: CABI Publishing

Holzer, Boris. 2006 "Political consumerism between individual choice and collective action: social movements, role mobilization and signaling," International Journal of Consumer Studies 30(5): 405415.

Humane Society International. 2017. Food Company Policies on Gestation Crates. http://www.humanesociety.org/assets/pdfs/farm/gestation-crate-policies.pdf (accessed $22 \mathrm{March}$ 2018).

Jaffee, Daniel, and Philip H. Howard. 2010 "Corporate cooptation of organic and fair trade standards." Agriculture and Human Values 27.4: 387-399.

King, Brayden G., and Nicholas A. Pearce. 2010. "The Contentiousness of Markets: Politics, Social Movements, and Institutional Change in Markets," Annual Review of Sociology 36: 249-267.

King, Leslie, and Julianne Busa. 2017. "When Corporate Actors Take Over the Game: The Corporatization of Organic, Recycling and Breast Cancer Activism," Social Movement Studies 16: 549-563.

Kingdon, John. 2010. Agendas, Alternatives and Public Policies New York: Longman.

Krystallis, Athanasios, Marcia Dutra de Barcellos, Jens Oliver Kügler, Wim Verbeke and Klaus G. Grunert (2009) "Attitudes of European citizens towards pig production systems," Livestock Science 126: $46-56$.

Lawson, Kirsten. 2014. "ACT Battery Cage and Sow Stall Ban a 'Message To Rest of Country'," Sydney Morning Herald. 26 February 2014.https://www.smh.com.au/environment/conservation/act-batterycage-and-sow-stall-ban-a-message-to-rest-of-country-20140227-33jcj.html. (accessed 6 March 2019).

Lee, Julian. 2007. "Pigs Sentenced to 10 More Cramped Years," Sydney Morning Herald. 23 April. https://www.smh.com.au/news/environment/pigs-sentenced-to-10-more-crampedyears/2007/04/22/1177180487707.html. (accessed 6 March 2019).

Levi-Faur, David. 2017. "Regulatory capitalism" in Regulatory Theory: Foundations and applications, edited by Peter Drahos. Canberra: ANU Press.

Locke, Sarina. 2010. Setting free the pigs. ABC Rural News 27 July 2010. http://www.abc.net.au/sitearchive/rural/content/2010/s2965415.htm (accessed 5 April 2019). 
Locke, Sarina. 2016. "Voluntary Sow Stall Phase-Out Deadline Approaches for Last 20 Per Cent," ABC Rural News 21 December. http://www.abc.net.au/news/rural/2016-12-21/voluntary-sow-stall-phaseout-deadline-approaches/8138450_(accessed 14 December 2017).

Long, Warwick. 2013. "Coles Defends Sow Stall Record," ABC Rural 10 January. http://www.abc.net.au/news/2013-01-10/coles-defends-sow-stall-record/6298428 (accessed 19 March 2018).

Marchant, J. N., A. R. Rudd, M. T. Mendl, D. M. Broom, M. J. Meredith, S. Corning, and P. H. Simmins. 2000. "Timing and Causes of Piglet Mortality in Alternative and Conventional Farrowing Systems," Veterinary Record 147: 209-214.

McInerney, John. 2004. "Animal Welfare, Economics and Policy”. Farm \& Animal Health Economics Division of the Department of Food, Environment and Rural Affairs. London: DEFRA.

Miele, Mara, and John Lever. 2013. "Civilizing the Market for Welfare Friendly Products in Europe? The Techno-Ethics of the Welfare Quality Assessment," Geoforum 48: 63-72.

Miele, Mara and Lever, John. 2014. "Improving animal welfare in Europe: Cases of comparative biosustainabilities" in Sustainable food systems: Building a new paradigm, edited by Terry Marsden and Adrian Morley. Earthscan.

Miele, Mara. 2011. "The Taste of Happiness: Free Range Chicken," Environment and Planning A 43: 2076-2090.

Meat and Livestock Australia. 2010. A New Food Guidance System for Australia - Foundation and Total Diets: Final Report. Sydney: Meat and Livestock Australia.

National Animal Welfare Advisory Committee. 2010. Animal Welfare (Pigs) Code of Welfare 2010. Wellington: New Zealand.

National Farm Animal Care Council. 2014. Code of Practice: For the Care and Handling of Pigs. Ottawa: Canadian Pork Council. http://www.nfacc.ca/pdfs/codes/pig code of practice.pdf. (accessed 10 December 2018).

Negowetti, Nicole E. 2018. "Establishing and Enforcing Animal Welfare Labeling Claims: Improving Transparency and Ensuring Accountability" Journal of Animal \& Natural Resource Law, 14:131-.

New South Wales Government. 2009. Animal Welfare Code of Practice - Commercial Pig Production 2009. https://www.dpi.nsw.gov.au/_data/assets/pdf_file/0003/313158/animal-welfare-code-ofpractice-commercial-pig-production.pdf. (accessed 10 December 2018).

OECD. 2018. Meat Consumption Indicator at https://data.oecd.org/agroutput/meat-consumption.htm (accessed 7 March 2019).

Ogus, Anthony. 1994. Regulation: Legal Form and Economic Theory. Oxford: Clarendon Press.

Park, H., Min, B. and Oh, S. 2017. Research trends in outdoor pig production - A review. AsianAustralasian Journal of Animal Sciences 30 (9): 1207-1214.

Parker, Christine. 2002. The Open Corporation: Effective self-regulation and democracy. Melbourne: Cambridge University Press.

Parker, Christine. 2014. "The Food Label as Governance Space: Free Range Eggs and the Fallacy of consumer choice. Recht der Werkelijkheid 35 (3): 101 - 133.

Parker, Christine, Rachel Carey and Gyorgy Scrinis. 2018. The Meat in the Sandwich: Welfare Labelling, Political consumerism and the Governance of Meat Chicken Production in Australia. Journal of Law and Society 45(3), 341-369.

Parker, Christine, Rachel Carey, Josephine De Costa and Gyorgy Scrinis. 2017. "Can the Hidden Hand of the Market be an Effective and Legitimate Regulator? The Case of Animal Welfare Under a Labeling for Consumer Choice Policy Approach," Regulation \& Governance 11: 368-387.

Parker, Christine, Rachel Carey and Gyorgy Scrinis. 2018a. Higher Welfare Labelling for Pig Meat: A Summary of Findings from the Project Regulating Food Labels - the Case of Free Range Food Products in Australia. Melbourne: University of Melbourne.

Parker, Christine, Rachel Carey and Gyorgy Scrinis. 2019. The consumer labelling turn in farmed animal welfare politics: from the margins of animal advocacy to mainstream supermarket shelves in Alternative food politics: From the margins to the mainstream edited by Michelle Phillipov and Katherine Kirkwood. London: Routledge. 
Parker, Christine, Hope Johnson and Janine Curll. 2019. Consumer power to change the food system? A critical reading of food labels as governance spaces: the case of acai berry superfoods. Journal of Food Law \& Policy 15(1): 1-48.

Pederson, Lene Juul. 2017. 'Overview of commercial pig production systems and their main welfare challenges' in Marek Špinka (ed) Advances in Pig Welfare. Woodhead Publishing.

Pickett, Heather, Dan Crossley, and Chris Sutton. 2014. Farm Animal Welfare: Past, Present and Future. Food Ethics Council <https://www.foodethicscouncil.org/uploads/publications/2014\%20FarmAnimalWelfare.pdf>.

Polanyi, Karl. 2001. The Great Transformation: The Political and Economic Origins of Our Time. Boston: Beacon Press. First published in 1944.

Primary Industries Standing Committee. 2008. Model Code of Practice for the Welfare of Animals: Pigs. $3^{\text {rd }}$ ed. Melbourne, Victoria: CSIRO Publishing.

Queensland Government. 2012. Animal Care and Protection Regulation 2012. https://www.legislation.qld.gov.au/view/whole/html/inforce/current/sl-2012-0141. (accessed 10 December 2018).

Richards, Carol, Geoffrey Lawrence, and David Burch. 2011. "Supermarkets and Agro-Industrial Foods," Food, Culture and Society 14: 29-47.

Rhodes, R. Tracy, Michael C. Appleby, Kathy Chinn, Lawrence Douglas, Lawrence D. Firkins, Katherine A. Houpt, Christa Irwin, John J. McGlone, Paul Sunberg, Lisa Tockach, and Robert W. Wills. 2005. "Task Force Report: A Comprehensive Review of Housing for Pregnant Sows," Journal of the American Veterinary Medical Association 227: 1580-1590.

RSPCA. 2018. Pigs - RSPCA Approved Farming Scheme Standards. November 2018. Canberra: RSPCA Australia.

RSPCA. 2017. What Are the Welfare Issues with Tail Docking and Tail Biting in Pigs?

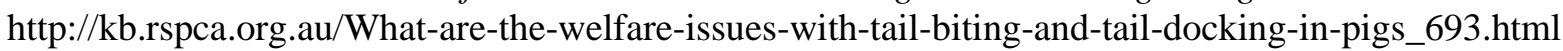
(accessed 8 March 2017).

Scientific Veterinary Committee of the European Union. 1997. The Welfare of Intensively Kept Pigs. Scientific Veterinary Committee.

Schneiberg, Marc, and Tim Bartley. 2008. "Organizations, Regulation, and Economic Behavior: Regulatory Dynamics," Annual Review of Law \& Social Sciences 4: 31-61.

Scrinis, Gyorgy, Christine Parker and Rachel Carey. 2017. "The Caged Chicken or the Free Range Egg? The Regulatory and Market Dynamics of Layer-hen Welfare in the UK, Australia and the USA". Journal of Agricultural and Environmental Ethics 30 (6): 783-808.

Shields, Sara, Paul Shapiro and Andrew Rowan. 2017. "A Decade of Progress Toward Ending the Confinement of Farm Animals in the United States," Animals 7: 1-28.

Siegford, J. M., Powers, W. and Grimes-Casey, H. 2008. Environmental aspects of ethical animal production. Poultry Sciences 87 (2): 380-386.

Smith, Dorothy E. 2005. Institutional Ethnography: A Sociology for People. New York: Rowman Altamira.

Smithfield Foods. 2018. Smithfield Foods Achieves Industry-Leading Animal Care Commitment, Unveils New Virtual Reality Video of its Group Housing Systems. 8 January.

https://www.smithfieldfoods.com/newsroom/press-releases-and-news/smithfield-foods-achievesindustry-leading-animal-care-commitment-unveils-new-virtual-reality-video-of-its-group-housingsystems (accessed 28 March 2018).

South Australian Government. 2012. Animal Welfare Regulations 2012. https://www.legislation.sa.gov.au/LZ/C/R/ANIMAL\%20WELFARE\%20REGULATIONS\%202012/ CURRENT/2012.187.AUTH.PDF. (accessed 10 December 2018).

Spooner, Jeffrey, Catherine A. Schuppli and David Fraser (2014) "Attitudes of Canadian citizens toward farm animal welfare: A qualitative study," Livestock Science 163: 150-158.

Streeck, Wolfgang. 2011. "Taking Capitalism Seriously: Towards an Institutionalist Approach to Contemporary Political Economy,” Socio-Economic Review 9: 137-167. 
Tasmanian Government. 2013. Animal Welfare (Pigs) Regulations 2013.

https://www.legislation.tas.gov.au/view/whole/html/inforce/current/sr-2013-035. (accessed 10

December 2018).

Thorslund, Cecilie, Margit Aaslyng and Jesper Lassen. 2017. Perceived importance and responsibility for market-driven pig welfare: Literature review. Meat Science 125: 37-45.

van Barneveld, R. J. 2013. "Nutritional Management of Group-Housed Gestating Sows - Key Challenges in the Transition from Stall-Housing Systems," Animal Production Science 53: 11491155.

Victorian Government. 2012. Pig Welfare Standards and Guidelines. http://agriculture.vic.gov.au/agriculture/animal-health-and-welfare/animal-welfare/animal-welfarelegislation/livestock-management-legislation-and-regulations/pig-welfare-standards-and-guidelines. (accessed 10 December 2012).

Victorian Greens. 2014. Victorian Greens to Introduce Bill to Ban Battery Cages and Sow Stalls and Clarify the Meaning of 'Free Range'. 6 September. https://greens.org.au/news/vic/victorian-greensintroduce-bill-ban-battery-cages-and-sow-stalls-and-clarify-meaning-free. (accessed 6 March 2019).

Voiceless. 2005. From paddocks to prisons: Pigs in NSW, Australia. Current practices, future directions. Sydney: Voiceless.

Voiceless. 2012. Sow Stalls: Voiceless Briefing. https://www.voiceless.org.au/reports-briefings. (accessed 10 December 2018).

Voiceless. 2013. Science and Sense: The case for Abolishing Sow Stalls. Sydney: Voiceless.

Voiceless. 2015. The Problems With 'Sow Stall Free'. https://www.voiceless.org.au/bansowstalls/problems-with-sow-stall-free (accessed 6 April 2018).

Western Australian Government. 2010. Animal Welfare (Pig Industry) Regulations 2010. https://www.legislation.wa.gov.au/legislation/prod/filestore.nsf/FileURL/mrdoc_30239.pdf/\$FILE/An imal\%20Welfare\%20(Pig\%20Industry)\%20Regulations\%202010\%20-\%20\%5B00-d002\%5D.pdf?OpenElement (accessed 10 December 2018).

White, Steven. 2013. "The Rationality of Animal Suffering in Australian law." Paper presented at Animal Suffering: From Science to Law conference, October 18-19 2012, Paris.

Woolworths Group. 2020. Animal Welfare. https://www.woolworthsgroup.com.au/page/community-andresponsibility/group-responsibility/responsible-sourcing/Animal_Welfare (accessed 13 January 2020). 


\section{University Library}

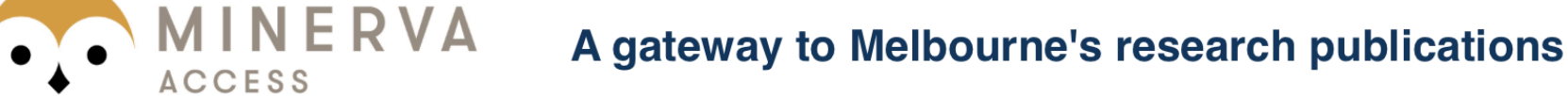

Minerva Access is the Institutional Repository of The University of Melbourne

Author/s:

Carey, R;Parker, C;Scrinis, G

Title:

How Free Is Sow Stall Free? Incremental Regulatory Reform and Industry Co-optation of Activism

Date:

2020-07-01

Citation:

Carey, R., Parker, C. \& Scrinis, G. (2020). How Free Is Sow Stall Free? Incremental Regulatory Reform and Industry Co-optation of Activism. LAW \& POLICY, 42 (3), pp.284-309. https://doi.org/10.1111/lapo.12154.

Persistent Link:

http://hdl.handle.net/11343/251791 